\title{
MIR375 wt Allele
}

National Cancer Institute

\section{Source}

National Cancer Institute. MIR375 wt Allele. NCI Thesaurus. Code C101665.

Human MIR375 wild-type allele is located in the vicinity of $2 q 35$ and is approximately 70 bases in length. This allele, which encodes MIR375 pre-miRNA, is involved in the modulation of gene expression. 